\begin{tabular}{|l|l|l||}
\hline \multicolumn{2}{|c|}{ PublisherInfo } \\
\hline \hline PublisherName & $:$ & BioMed Central \\
\hline \hline PublisherLocation & $:$ & London \\
\hline \hline PublisherImprintName & $:$ & BioMed Central \\
\hline \hline
\end{tabular}

\title{
Venter in new venture
}

\begin{tabular}{|l|l|l||}
\hline \multicolumn{2}{|c||}{ ArticleInfo } \\
\hline \hline ArticleID & $:$ & 4556 \\
\hline \hline ArticleDOI & $:$ & 10.1186 /gb-spotlight-20020816-01 \\
\hline \hline ArticleCitationID & $:$ & spotlight-20020816-01 \\
\hline \hline ArticleSequenceNumber & $:$ & 222 \\
\hline \hline ArticleCategory & $:$ & Research news \\
\hline ArticleFirstPage & $:$ & 1 \\
\hline \hline ArticleLastPage & $:$ & 2 \\
\hline \hline & & RegistrationDate : 2002-8-16 \\
\hline ArticleHistory & $:$ & OnlineDate \\
\hline \hline ArticleCopyright & $:$ & BioMed Central Ltd2002-16 \\
\hline \hline ArticleGrants & $:$ & \\
\hline \hline ArticleContext & $:$ & 130593311 \\
\hline \hline
\end{tabular}




\section{Jim Kling}

Email: jkling@nasw.org

J. Craig Venter, formerly of Celera Genomics, announced plans today to open a 40,000-square foot facility in Rockville, Maryland, that will expand by several-fold the sequencing capacity of The Institute for Genomic Research (TIGR).

In April, Venter, a TIGR board member, announced the creation of the Center for the Advancement of Genomics, to study the public policy aspects of genomics, and the Institute for Biological Energy Alternatives, to investigate microbial sources of energy. Both projects, which are supported by Venter's Science Foundation, are adding a burden to TIGR's existing sequencing facility, and the new facility will ease that burden, Venter told us in a telephone interview.

TIGR's existing facility, which now sequences genomes base by base, will eventually be converted to a genome closure facility that will fill in gaps at the end of projects. "For microbial genomes that (function) is very important, because $90 \%$ of most of the genome is genes, while only $1.1 \%$ of the human genome is genes. So gaps in humans don't really matter," Venter said.

Venter also expects the new center to greatly decrease the cost of sequencing, while increasing speed, by using new high-throughput technology and microvolume procedures that should reduce the cost of reagents. The goal is to get full-genome sequencing down to a cost of $\$ 1,000$ to $\$ 3,000$ and to speed sequencing in order to "push the personalized medicine paradigm by sequencing genomes" in the time it takes to have a conversation," he said.

The institute should open its doors by the end of the year. Although it does not yet have a title, there is an internal naming competition under way. "Outside submissions are certainly welcome, too," Venter said.

\section{References}

\section{Celera Genomics, [http://www.celera.com/]}

2. The Institute for Genomic Research press release, [http://www.tigr.org/new/ press_release_8-15-02.shtml]

3. The Institute for Genomic Research, [http://www.tigr.org/]

4. Center for the Advancement of Genomics, [http://www.tcag.org/]

5. Institute for Biological Energy Alternatives, [http://www.bioenergyalts.org/] 